\title{
DYNAMICS OF BOG-PINE-DOMINATED MIRES IN THE JURA MOUNTAINS, SWITZERLAND: A TENTATIVE SCHEME BASED ON SYNusial Phytosociology
}

\author{
François Freléchoux $^{1)}$, Alexandre Buttler ${ }^{2,3)}$ \& François Gillet ${ }^{1)}$ \\ 1) Laboratoire d'Ecologie végétale et de Phytosociologie, Institut de Botanique de l'Université, \\ Rue Emile-Argand 11, CH-2007 Neuchâtel, Switzerland; fax +41 327182101 , \\ E-mail francois.frelechoux@bluewin.ch, francois.gillet@bota.unine.ch
}

2) Laboratoire de Chrono-écologie, UMR 6565 CNRS, UFR des Sciences et Techniques, 16 Route de Gray, Université de Franche-Comté, F-25030 Besançon, France; fax +33381666568 ,

E-mail alexandre.buttler@bota.unine.ch

3) Swiss Federal Institute for Forest, Snow and Landscape Research, Antenne romande, clo EPFL, CH-1015 Lausanne, Switzerland

Keywords: Drainage, Peat bog, Pinus uncinata var. rotundata, Synusial phytosociology, Vegetation dynamics

\begin{abstract}
A description of the bog-pine (Pinus uncinata var. rotundata) dominated vegetation of uncut oligotrophic mires affected by drainage is given. Surveys were carried out at 17 sites along the Jura Mountains (Switzerland and France) in 1993, 1994, and 1995. Raised bogs of the Jura are generally of small size, and most vegetation changes in them have occurred as a result of the indirect impact of peat cutting. This activity led to the peat drying out and to colonization by trees, in particular by bog-pines.

Integrated synusial phytosociology was used to describe the vegetation where bog-pine, spruce, and birch occur. Two spatio-temporal levels of organization were considered: the synusia and the phytocoenosis. At the phytocoenosis level, four vegetation types representing bog-pine stands of uncut and deep oligotrophic peats are described with their constitutive synusial composition. They represent: (1) phytocoenoses developing in the open, wet central parts of the bogs, where trees are scattered and of small size, (2) phytocoenoses with layered tree stands of medium size and with a higher density, and (3) phytocoenoses with tall trees, developing generally near the edge of the bogs or close to peat cuttings. A generalized qualitative dynamic model of the vegetation in relation to the development of bog-pine trees was developed. It shows the spatial and temporal organization of the constituent synusiae, as well as other underlying hypothetical functional relations.

The different bog-pine-dominated vegetation types described in this study appear to have coexisted since the origin of the Jura bogs as a result of local polyclimaxes induced by differential waterlogged situations. They probably all belong to the same (primary) successional series, but have been affected by both autogenic and allogenic processes. During the development of the bogs the balance between the different communities changed. In particular, the vegetation types with dense and tall pine trees have undergone a drastic expansion since the Jura bogs were first affected by drainage.
\end{abstract}

\section{INTRODUCTION}

The raised bogs of the Jura Mountains are generally of small size, most of them less than 20 ha, which is typical for this karst environment. Impermeable autochthonous and allochthonous substrates, synclines and ancient glacier valleys with moraine ridges are features that explain the local geographical distribution of these bogs. Despite these limiting features, the growth dynamics of the Jura bogs were considerable during the postglacial period, leading 
to the formation of peat of several metres deep. This was an opportunity for the peat-cutting industry, which was important mainly from the 18th century to the middle of the 20th century. Today, about $90 \%$ of the original bog surfaces in Switzerland have disappeared with only about 1,500 ha remaining (GRÜNIG et al. 1984, 1986). Even where entire uncut bogs are found, vegetation changes have occurred as a result of the indirect impact of peat-cuttings which took place in the vicinity. This activity led to the drying out of peat and to the colonization by tall bog-pines (Pinus uncinata var. rotundata). REILLE (1991) stressed the significant increase in pine-pollen deposition in the recent past, in comparison with the rates established for earlier layers within the peat profiles.

The bog-pine - Pinus uncinata var. rotundata (LINK) ANTOINE - is considered by SANDOZ $(1982,1987)$ to be a hybrid between $P$. uncinata RAMOND, which is a tall and monocormic species located in the western part of Europe (Pyrenees) and $P$. mughus SCOP., which is a prostrated polycormic species with an eastern distribution in Europe. Bog-pine is distributed between the Jura Moutains and the High Tatras, including the Vosges, the Black Forest, the Bavarian Forest, Southern Bohemia, North-West Austria, mountain ranges in the northern part of the Czech Republic, and the Bohemian-Moravian Uplands (NEUHÄUSL 1972, SANDOZ 1987, FELDMEYER-CHRISTE 1990).

In histosols, the ground-water table is an important limiting factor for the development of trees. Its influence on the survival and growth of seedlings has been demonstrated for many bog-tree species (MüLlER-DOMBOIS 1964, LIEFFERS \& RoTHWELL 1986, 1987). Drainage is known to stimulate the growth of a number of bog trees (SEPPALA 1969, PAYANDEH 1973, STANEK 1977, STRAVINSKENE 1983, DANG \& LIEFFERS 1989) and this applies also in the case of Pinus uncinata var. rotundata (GRÜNIG 1955, SCHULTHESS 1990, SCHWEINGRUBER 1996). The moss carpet is another factor that plays an important role in the rooting of seedlings. OHLSON \& ZACKRISSON (1992) showed that a Sphagnum carpet, because it is moist, promotes the seed germination of some Picea and Pinus species more than drier Pleurozium schreberi carpets. The high moisture content of the Sphagnum carpet, however, is a threat to the survival of these seedlings.

While some authors consider the bog-pine-dominated mire vegetation in the Jura to be a local climax (RICHARD 1961, MATTHEY 1964, ROYER et al. 1978, BUTTLER et al. 1983), others disagree and suggest that in some mires the bog-pines might have been planted (FELDMEYER-CHRISTE 1990, REILLE 1991). Some authors classified this kind of vegetation as a Pino rotundatae-Sphagnetum KÄSTNER et FLÖSSNER 1933 (CHASTAIN 1952, RICHARD 1961, nomenclature according to OBERDORFER 1977), but only those communities on drier soils and with dense populations of tall trees were included in these studies. The bog-pine also develops in the wetter parts of the mires, where it grows to a smaller height, and is either isolated or in small groups. Our observations suggest that there is more than one type of bog-pine-dominated vegetation, varying within the broad range of ecological conditions where bog-pines are found. This is reflected in the uncertainties of the literature when classifying the bog-pine-dominated vegetation of Central European mires: some authors include the Pino rotundatae-Sphagnetum in the class Vaccinio-Piceetea BR.-BL. in BR.-BL. et al. 1939 (OBERDORFER 1957, RICHARD 1961, KRISAII 1960), and others in the class Oxyccoco-Sphagnetea BR.-BL. et TX. 1943 (MoORE 1968, NeuHÄUSL 1969, 1972, DiERSSEN 1977. 1980, ROYER et al. 1978). More recently, OBERDORFER (1992) and NEUHÄUSL (1992) referred to the pine-dominated communities of tall trees with a paucity of mire species as Vaccinio uliginosi-Pinetum rotundatae OBERD. 1934 (class Vaccinio-Piceetea). 
This paper describes the bog-pine-dominated vegetation of the uncut oligotrophic mires of the Jura Mountains. A typology is given based on the synusial organization of the phytocoenoses in order to formulate a theoretical dynamic qualitative model relative to the water level and the extent to which the bogs have dried out.

\section{METHODS}

\section{Study area}

The survey of tree-dominated bog vegetation was carried out at 17 sites along the Jura Mountains (15 sites in Switzerland and 2 sites in France) in 1993, 1994, and 1995, within the geographical limits: $46^{\circ} 33^{\prime}$ to $47^{\circ} 17^{\prime} \mathrm{N}, 6^{\circ} 5^{\prime}$ to $7^{\circ} 11^{\prime} \mathrm{E}$ and at altitudes ranging between 930 and $1,250 \mathrm{~m}$ a.s.1. The climate is predominantly oceanic, under the combined influence of humid winds from the Atlantic (Westerlies) and continental anticyclones, with a mean annual precipitation of about $1,500 \mathrm{~mm}$. Rainfall is rather low from February to April and in October (monthly 100-110 mm), and high in June (monthly $>140 \mathrm{~mm}$ ). With reference to MATTHEY (1971), the mean annual air temperature in bogs of the study area is about $4{ }^{\circ} \mathrm{C}$; monthly means in the period from June to September range from $9.7^{\circ} \mathrm{C}$ to $13.3{ }^{\circ} \mathrm{C}$, with values under $0^{\circ} \mathrm{C}$ being possible throughout the year. Air humidity is saturated during the night and misty conditions are frequent.

\section{Integrated synusial approach}

Integrated synusial phytosociology (GILlET et al. 1991, GILLET \& GALLANDAT 1996) was used to describe the vegetation. Based on the BRAUN-BLANQUET (1964) approach, this method aims at describing complex vegetation structures and at emphasizing the dynamic links between the various constituent elements. Among several spatio-temporal organization levels, we only considered the first two levels (Fig. 1):

(i) The synusia (BARKMAN 1973) is an elementary one-layered concrete vegetation unit (patch) directly linked to uniform environmental conditions (microclimate, microtopography, soil, biotic factors). Thus, every synusia is a floristically, physiognomically and ecologically homogeneous vegetation unit. In the field, the vegetation structure is first assessed and the vegetation stand divided into synusiae. A synusial relevé is a quantitative description (abundance-dominance values according to BRAUN-BLANQUET 1964) of the species occurring in the sample plot of any selected concrete patch.

(ii) The phytocoenosis (GuINOCHET 1973, BARKMAN 1973, WESTHOFF \& VAN DER MAAREL 1978 ) is a complex of synusiae that are functionally strongly linked both in space (mosaics, stratification) and time (seasonal aspects, regeneration cycles). The phytocoenotic relevé consists of a quantitative description (abundance-dominance values according to BRAUN-BLANQUET 1964) of the elamentary synusial syntaxa observed in a concrete phytocoenosis.

Synusial phytosociology has several advantages over the Braun-Blanquet method. For instance: (1) It is a very detailed approach to studying vegetation aiming at discerning and interpreting both the horizontal and vertical micro-heterogeneity of the phytocoenosis. The synchronic approach can also lead to the interpretation of succession patterns. (2) Vegetation layers within the phytocoenosis may represent different environmental conditions. For example, abiotic conditions such as water-table depth, light or $\mathrm{pH}$ are very different for a bog-pine tree of the dominant layer and for a Sphagnum plant in the moss carpet. Further, 
1a)

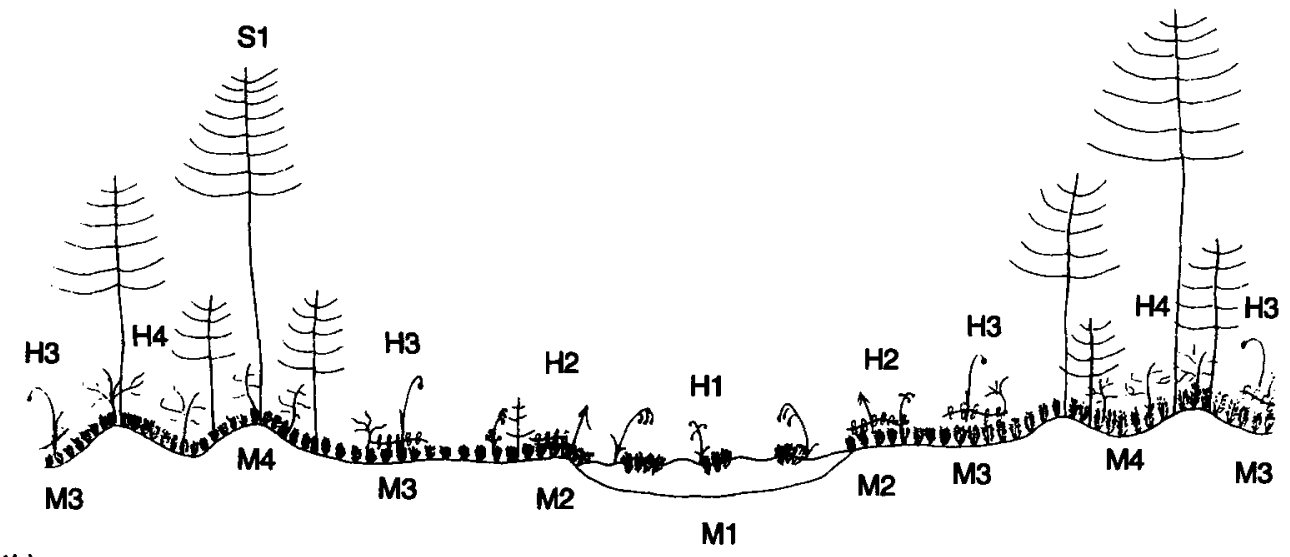

1b)

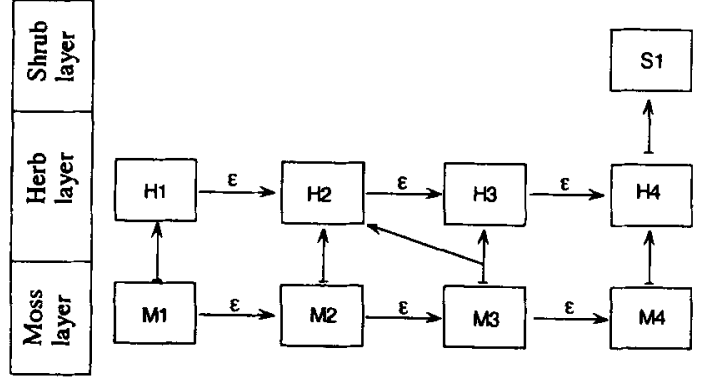

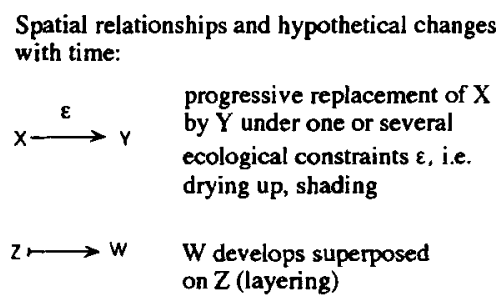

Fig. 1. Theoretical example of the synusial organization within a phytocoenosis representing a wet central part of a bog with hollows, wet lawns and hummocks sparsely covered by small bog-pine trees. 1a: Sketch of the location of the different synusiae in the phytocenosis. $1 \mathrm{~b}$ : Dynamic diagram representing the spatial and temporal hypothetical relationships between the synusiae in relation to tree colonization. $\mathrm{Ml}$ and $\mathrm{H} 1$ : moss and herb synusiae of hollows; M2 and H2: moss and herb synusiae of wet lawns; M3 and H3: moss and herb synusiae of dry lawns; M4 and H4: moss and herb synusiae of hummocks; S1: shrub synusia of bog-pine.

changes in the vegetation, either as a result of natural evolution or anthropic impact, may occur variously in the different layers.

The vegetation was described by means of 94 phytocoenotic relevés of the main woodland communities dominated by bog-pine (Pinus uncinata var. rotundata), spruce (Picea abies) and pubescent birch (Betula pubescens) (FRELÉCHOUX 1997). Bog-pine woodlands were found on deep uncut bogs. Spruce forests were found along the edges of uncut raised bogs and colonized ditches after exploitation. Birch woodlands are scarcer and most often found on cleared, unexploited surfaces and in the wetter ditches. 767 synusial relevés were carried out simultaneously in all these phytocoenoses. A typology was carried out by comparing and classifying these relevés in synusial elementary syntaxa (elementary typological units of this organization level) with numerical tools combining various methods step-by-step using MULVA-5 software (WILDI \& ORLÓCI 1996, WILDI 1989). More precisely, three macro-applications were performed separately on the data of each layer: moss, herb, shrub and tree. The first application yielded various classifications: (i) a classification of relevés and species based on presence-absence transformed data, van der Maarel similarity matrix and complete linkage clustering; (ii) a classification of relevés based on the Euclidean distance 


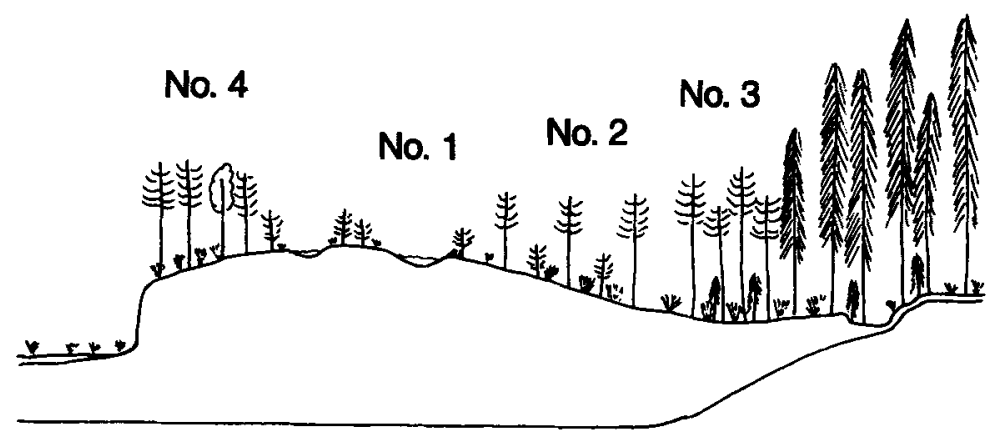

Fig. 2. The four major bog-pine-dominated vegetation types in the uncut oligotrophic mires of the Jura. No. 1: coenotaxon with Pinus uncinata var. rotundata, Andromeda polifolia, and Sphagnum rubellum in open and wet situations; No. 2: coenotaxon with Pinus uncinata var. rotundata, Vaccinium uliginosum, and Sphagnum fuscum with slightly denser tree canopies; No. 3: coenotaxon with Pinus uncinata var. rotundata, Vaccinium myrtillus, Sphagnum capillifolium, and Dicranum polysetum of dense and tall tree stands near the edge of the mire and its bordering spruce forest; No. 4: coenotaxon with Pinus uncinata var. rotundata, Betula pubescens, Vaccinium myrtillus, Sphagnum capillifolium, and Dicranum polysetum in rather dense and tall tree stands near the peat-cutting area.

matrix of the co-ordinates of principal coordinate analysis and minimum variance clustering; (iii) a classification of relevés based on the Euclidean distance matrix of the co-ordinates of correspondence analysis of presence-absence transformed data and minimum variance clustering and (iv) a classification of relevés and species based on square-root transformed data and the adjustment of vectors to unit length, on a cross-product similarity matrix and mimimum variance clustering. The optimal number of groups of relevés and species was determined after comparing, for the various classifications, the successive fusion levels in the clusterings. The second application compared the combined classifications by mean of concentration analyses. Based on the best combination of relevés and species classification, the third application led to the re-allocation of relevés and species in order to optimize the final classification by means of a sum of squares K-means algorithm. In the same way as for the synusiae, the phytocoenotic relevés were compared using the same numerical tools and classified into elementary coenotaxa ( $=$ the elementary typological units of this organization level).

The ecological indicator values of the species for important factors such as soil moisture, light, nutrient status and acidity were used according to LANDOLT (1977) for vascular plants and DÜLL (in ELLENBERG et al. 1991) for the bryophytes. The mean values for each synusia were calculated by weighting the ecological values of the species with their dominance percentage. The mean and the standard deviation were calculated for each synusial elementary syntaxon. Field drawings representing the location of each synusia within each phytocoenosis (see example in Fig. 1a) and the calculated mean ecological indicator values served to interpret spatial and temporal relationships and thus to formulate the functional hypotheses that are represented in the dynamic schemes (Fig. 1b). A comparison of all the individual dynamic schemes of each phytocoenosis allowed a qualitative generalized model to be developed that summarizes the hypothetical processes characterizing the succession from unwooded peatlands to bog-pine-dominated vegetation.

The nomenclature of vascular plants follows TuTIN et al. (1964-1980), and that of bryophytes CORLEY et al. (1981) and GROLLE (1983). 
Table 1. Synthetic tabular representation of the elementary coenotaxa that constitute the bog-pine-dominated vegetation of the uncut oligotrophic mires of the Jura Mountains. Each coenotaxon is described by a list of syntaxa, numbered according to Tab. 2 to 5 and Appendix. Relative frequency (RF) classes are indicated for each syntaxon in each coenotaxon; $r$ : syntaxon represented in less than $10 \%$ of the relevés or in a single relevé; I: $10 \% \leq \mathrm{RF} \leq 20 \%$; II: $20 \%<\mathrm{RF} \leq 40 \%$; III: $40 \%<$ RF $\leq 60 \%$; IV: $60 \%<$ RF $\leq 80 \%$; V: RF $>80 \%$. Mean abundance-dominance values are also indicated according to the Braun-Blanquet scale. Syntaxa that do not show relative frequencies of $10 \%$ or higher in any of the coenotaxa are not listed. Those syntaxa given in Tab. 2 to 5 and used in the generalized qualitative dynamic model (Fig. 3) are indicated with an asterisk (*).

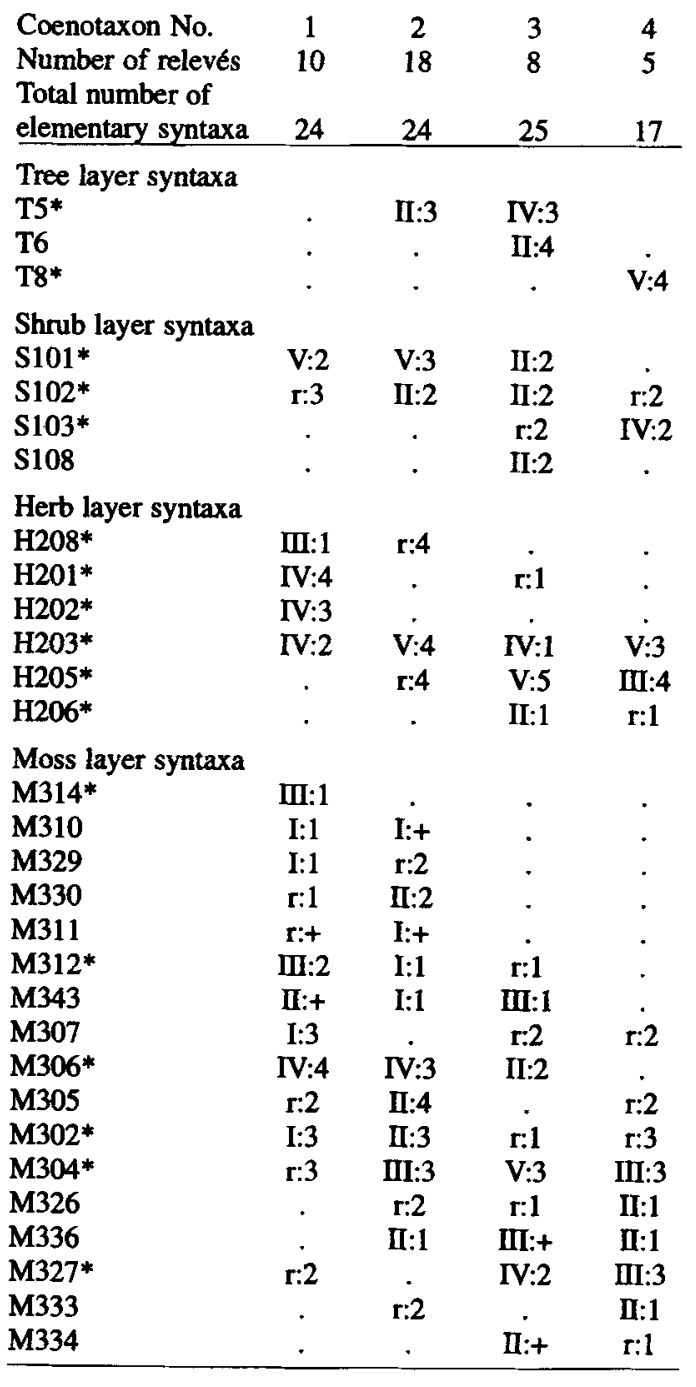

\section{RESULTS}

The numerical analysis of the 767 synusial relevés led to 83 synusial elementary syntaxa (Freléchoux 1997): 12 for the tree synusiae, 10 for the shrub synusiae, 14 for the herb synusiae, 47 for the moss and lichen synusiae. The numerical analyses of the 94 phytocoenotic relevés enabled us to identify 12 elementary coenotaxa: 5 for the bog-pine-dominated vegetation, 2 for the spruce-dominated vegetation and 5 for the pubescent birch-dominated vegetation. Among the 5 bog-pine-dominated coenotaxa, 4 are characteristic of uncut deep oligotrophic peats (Fig. 2) and these are the primary objects of interest in this paper. The main elementary syntaxa occurring in these coenotaxa are presented in Appendix. Tab. 1 presents the 4 elementary coenotaxa with their elementary syntaxa assemblages and Tab. 2 to 5 give the species assemblages of the main characteristic and differential elementary syntaxa that have been used in the qualitative generalized dynamic model of Fig. 3 and which explain most of the spatial structure of the vegetation.

Coenotaxon No. 1 is a community type with Pinus uncinata var. rotundata, Andromeda polifolia, and Sphagnum rubellum. In it, the trees are scattered and of small size. They are generally spread out or growing on hummocks alternating with hollows and very wet lawns. This coenotaxon includes some associations recognized in classical phytosociology such as: Caricetum limosae BR.-BL. 1921, Sphagnetum magellanici (MALCUTT 1929) KÄSTNER et FLÖSSNER 1933 and Pino rotundatae-Sphagnetum KÄSTNER et FLÖSSNER 1933 (pro parte) (nomenclature after OBERDORFER 1977). Coenotaxon No. 2 is a community type with Pinus uncinata var. rotundata, Vaccinium uliginosum, and Sphagnum fuscum. It represents phytocoenoses in intermediate situations 
Phytocoenoses's

structure

Wooded stages

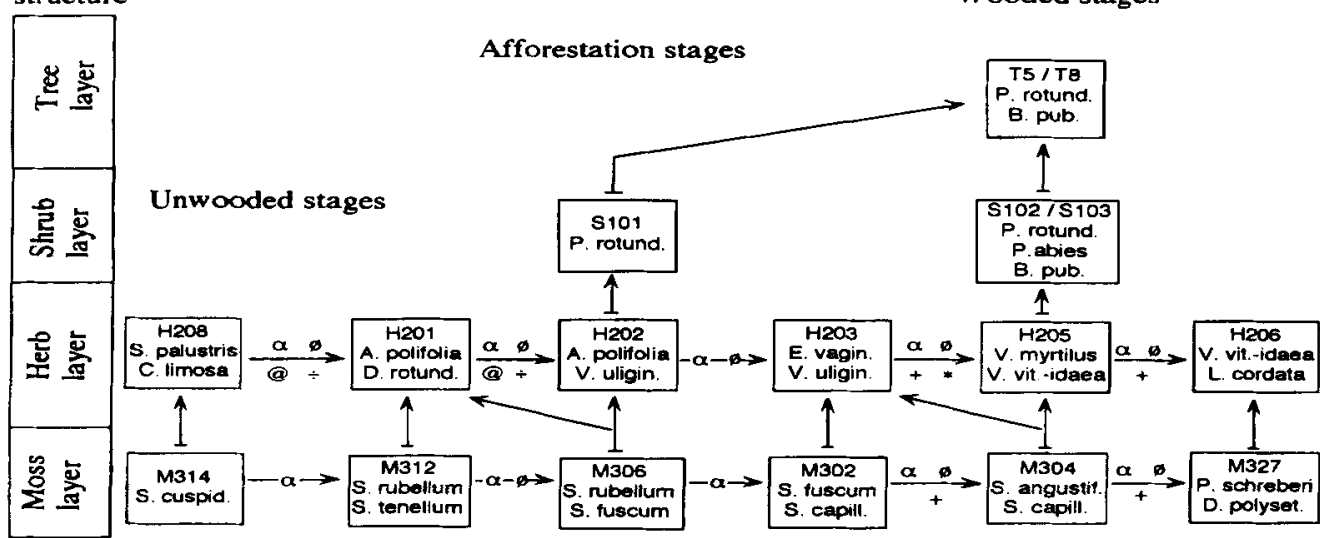

Fig. 3. Generalized qualitative dynamic model of the vegetation in relation to the development of bog-pine trees on oligotrophic mires affected by drainage. The diagram is drawn with the elementary syntaxa occurring in the four bog-pine-dominated coenotaxa described in Fig. 2 and in Tab. 2 to 5. The hypothetical relations are derived from the synchronical description of the vegetation and from comparisons of the calculated ecological significance of the different syntaxa (Fig. 4). Lichen or hepatic-dominated synusiae are not included and only the main syntaxa explaining most of the vegetation spatial structure are considered. Spatial relationships and hypothetical changes with time: $X-\varepsilon \rightarrow Y-$ progressive replacement of $X$ by $Y$ under an ecological constraint $\varepsilon$. Constraints are: $\alpha$ - soil becomes drier; @ - soil becomes more acid; + - soil becomes less acid; * - soil nutrients increase, peat mineralization; +- soil nutrients decrease; $\emptyset$ - light decreases; $\mathrm{Z} \mapsto \mathrm{W}-\mathrm{W}$ develops superposed on $\mathrm{Z}$ (layering).

with layered tree stands of medium size and high density. Vigorous Vaccinium uliginosum forms a dense layer. This coenotaxon includes a number of recognized associations such as: Sphagnetum magellanici (incl. Sphagnetum fusci LUQUET 1926) and Pino rotundatae-Sphagnetum (pro parte). Coenotaxon No. 3 is a community type with Pinus uncinata var. rotundata, Vaccinium myrtillus, Sphagnum capillifolium, and Dicranum polysetum comprising tall tree stands near the mire edge and its bordering spruce forest. Coenotaxon No. 4 is a community type with Pinus uncinata var. rotundata, Betula pubescens, Vaccinium myrtillus, Sphagnum capillifolium, and Dicranum polysetum consisting of rather dense tall tree stands adjacent to peat-cuttings. Its vegetation is closely related to coenotaxon No. 3, although with birch developing. In these two last coenotaxa, the Vaccinium myrtillus layer is very vigorous. Together they include a number of classical associations including Pino rotundatae-Sphagnetum (pro parte) and Vaccinio uliginosi-Pinetum rotundatae. Species of the Oxyccoco-Sphagnetea are rare, those of the Vaccinio-Piceetea being more frequent.

The mean ecological indicator values of the herb and moss synusia are shown in Fig. 4, and the generalized qualitative model of the vegetation dynamics on oligotrophic mires affected by drainage is given in Fig. 3. In the course of tree colonization, some of the elementary syntaxa of hollows (M314, H208) and of wet lawns (H201, H202, M312, M306) disappear, whereas the Vaccinium strata gain in importance, first dominated by Vaccinium uliginosum (H203) and then by V. myrtillus (H205). This dynamic process is marked by shifts in the combination of mosses. Species such as Sphagnum cuspidatum, S. tenellum, S. rubellum, $S$. fuscum, and $S$. capillifolium are transient (ANDRUS et al. 1983), while $S$. angustifolium and $S$. magellanicum, which have a greater ecological amplitude are, therefore, less affected by the tree colonization (Tab. 5). The spread of Sphagnum tenellum, in such bogs, may be due 

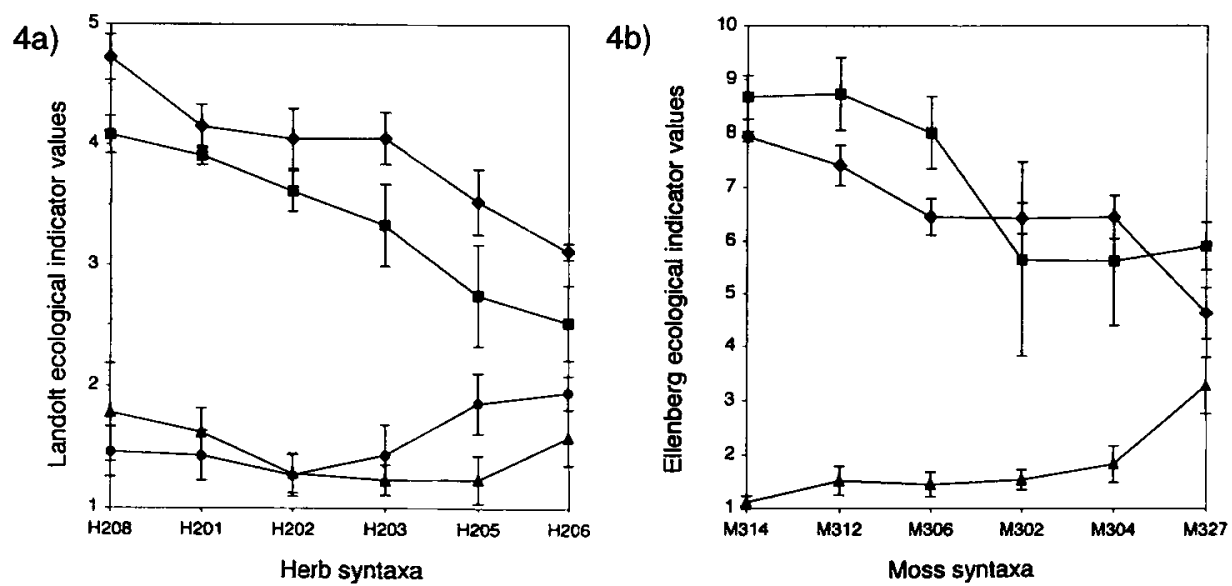

Fig. 4. Mean ecological indicator values \pm 1 standard deviation for the herb and moss syntaxa, numbered and ordered according to Tab. 4 and 5 and Fig. 3. Scales for ecological indicator values are given according to LANDOLT (1977) for the herb syntaxa (Fig. 4a, scale from 1 to 5) and according to ELLENBERG et al. (1991) for the moss synusiae (Fig. 4b, scale from 1 to 9). Soil humidity value $F(\diamond)$ : 1 (dry) to 5 or 9 (wet); Light value $L(\mathbb{\square})$ : 1 (shade) to 5 or 9 (light); Reaction value $R(\mathbf{A})$ ) 1 (acid) to 5 or 9 (neutral to alkaline); Nutrient value $\mathbf{N}(\bigcirc)$ : 1 (nitrogen poor) to 5 or 9 (nitrogen rich).

to the hygrophilous nature of the species, which can cope with summer droughts. Some other mosses are also favoured by dryness in the open and well-lit environments of the bogs; these include Aulacomnium palustre, Dicranum affine, and Polytrichum strictum. In more shaded locations beneath dense canopies of pine trees, species such as Hylocomium splendens, Pleurozium schreberi, Dicranum polysetum, and Ptilium crista-castrensis increase in abundance on the driest hummocks, competing with the Sphagnum species. Seedlings of Pinus were more frequently encountered in the open and wet situations (H201, H202) or in the presence of a low Vaccinium uliginosum layer (H203). By contrast, Picea abies and Betula pubescens seedlings were more frequent in dry situations with a Vaccinium myrtillus and V. vitis-idaea layer (H205, H206) (Tab. 4) and were missing in the wet and open parts of the bogs (H208, H201, H202). Thus, it appears that seedlings and saplings of Pinus uncinata var. rotundata survive at a better rate in more open and wet environments, which confirms the observations of SCHMID et al. (1995).

\section{DISCUSSION}

The four coenotaxa that describe the bog-pine-dominated vegetation on uncut oligotrophic mires affected by drainage in the Jura Mountains are often found in concentric arrangements on small bogs that are often bog remnants. They can be easily distinguished if their synusial organization is considered, including both vertical layers and horizontal patches.

A dendroecological study of the tree stands (FrELÉCHOUX 1997, FRELÉCHOUX et al. 2000) allowed interesting insights into the vegetation dynamics. In coenotaxon No. 1, representing open and wet situations, pine trees were small $(0-5 \mathrm{~m})$ and showed reduced width and top growth. Their populations consisted of individuals of uneven ages. In coenotaxon No. 2 , showing a slightly denser tree canopy, trees were of medium size (0-8 m) and also of uneven ages, but some individuals were very old (maximum 375 years old). By contrast, in coenotaxa No. 3 and No. 4, where dense tree stands have developed, most trees grew fast, reaching 
Table 2. Synthetic tabular representation of the principal tree synusial elementary syntaxa of bog-pine-dominated vegetation in the uncut oligotrophic mires of the Jura Mountains. Relative frequency (RF) classes are indicated for each species in each syntaxon; $r$ : species represented in less than $10 \%$ of the relevés or in a single releve; I: $10 \% \leq \mathrm{RF} \leq 20 \%$; II: $20 \%<\mathrm{RF} \leq$ 40\%; III: $40 \%<\mathrm{RF} \leq 60 \%$; IV: $60 \%<\mathrm{RF} \leq 80 \%$; V: RF $>$ $80 \%$. Mean abundance-dominance values are indicated according to the Braun-Blanquet scale. Species that do not show relative frequencies of $10 \%$ or higher in any of the syntaxa are not listed. A short description of each syntaxon is given in Appendix.

\begin{tabular}{lcc} 
Tree layer syntaxon & T5 & T8 \\
Number of relevés & 11 & 7 \\
Total number of species & 1 & 3 \\
\hline Pinus uncinata var. rotundata & V:5 & V:4 \\
Betula pubescens &. & V:1 \\
Picea abies &. & V:1 \\
\hline
\end{tabular}

Table 3. Synthetic tabular representation of the principal shrub synusial elementary syntaxa of bog-pine-dominated vegetation in the uncut oligotrophic mires of the Jura Mountains (see complete explanation in Tab. 2). A short description of each syntaxon is given in Appendix. Rare species are not listed.

\begin{tabular}{lccc} 
Shrub layer syntaxon & $\$ 101$ & $\$ 102$ & $\$ 103$ \\
Number of relevés & 42 & 10 & 20 \\
Total number of species & 1 & 3 & 6 \\
\hline Pinus uncinata var. rotundata & V:5 & V:5 & V:2 \\
Betula pubescens &. & III:+ & V:4 \\
Picea abies &. & III:+ & III:1 \\
Sorbus aucuparia &. &. & I:+ \\
\hline
\end{tabular}

heights of 10-15 $\mathrm{m}$ and constituting even-aged and relatively young populations (maximum 150 years). These observations highlight the distinct population dynamics of Pinus in these four different communities.

The primary vegetation succession that leads towards Pinus forest is outlined in Fig. 5. When comparing the vegetation units described by NEUHÄUSL (1992) with the coenotaxa described here, it appears that the Pino rotundatae-Sphagnetum, which is considered to be a local climax, corresponds to coenotaxa No. 1 and No. 2, which have trees of small to medium size. On the other hand, the Vaccinio uliginosi-Pinetum, which is considered to be a post-climax community, corresponds well to coenotaxa No. 3 and No. 4, which both have tall trees. In fact, the coenotaxa belong to the same (primary) successional series, but have been affected by both autogenic and allogenic processes. According to ZOBEL (1988), increasing oligotrophy and acidity are the main forcing functions of autogenic processes. On the other hand, it seems clear that bog evolution has been conditioned by allogenic factors such as climate shifts over thousands of years and more recently by such anthropic impacts as drainage and peat cutting. It is, therefore, permissible to consider the first part of the dynamics (coenotaxa No. 1 and No. 2) as being chiefly dependent on autogenic processes and the second part (coenotaxa No. 3 and No. 4) on allogenic processes. The later stages result from the combination of the indirect effects of active drainage in the vicinity (peat cutting) and of natural drainage that is more pronounced in small raised bogs. Although GUINOCHET (1955) suggested that there is a succession from pine forest towards spruce forest, this is not possible on uncut oligotrophic, poorly-drained, deep-peat soils since spruce trees growing on these are generally of limited size and show obvious signs of chlorosis.

The high mortality of pine trees at some sites suggests that succession could proceed towards wetter heathlands. The subsidence and compactness of the peat soils as a result of intensive mineralization could explain this phenomenon (SCHNEEBELI 1991, SCHULTESS 1990, SCHWEINGRUBER 1996). This would also indicate that a cyclic process could take place with an alternation of wooded, dry peat-bogs and open wet mires. Indeed, tree establishment would require favourable ecological conditions, in particular enough light and moisture, which are 
Table 4. Synthetic tabular representation of the principal herb synusial elementary syntaxa of bog-pine-dominated vegetation in the uncut oligotrophic mires of the Jura Mountains (see complete explanation in Tab. 2). A short description of each syntaxon is given in Appendix. Rare species are not listed.

\begin{tabular}{|c|c|c|c|c|c|c|}
\hline $\begin{array}{l}\text { Herb layer syntaxon } \\
\text { Number of relevés } \\
\text { Total number of species }\end{array}$ & $\begin{array}{c}\mathrm{H} 208 \\
7 \\
27 \\
\end{array}$ & $\begin{array}{c}\mathrm{H} 201 \\
10 \\
21\end{array}$ & $\begin{array}{c}\mathrm{H} 202 \\
8 \\
13 \\
\end{array}$ & $\begin{array}{c}\mathrm{H} 203 \\
50 \\
37 \\
\end{array}$ & $\begin{array}{c}\mathrm{H} 205 \\
25 \\
38 \\
\end{array}$ & $\begin{array}{c}\mathrm{H} 206 \\
7 \\
14 \\
\end{array}$ \\
\hline Carex chordorrhiza & II:1 & r:t+ & . & r & . & . \\
\hline Carex limosa & $\mathrm{V}: 2$ & $r: t$ & . & . & • & . \\
\hline Scheuchzeria palustris & V:1 & II:+ & . & & - & . \\
\hline Eriophorum angustifolium & III:+ & II:1 & . & $r: t$ & . & . \\
\hline Carex echinata & III: 1 & II:t & . & $\mathrm{I}: 1$ & . & . \\
\hline Menyanthes trifoliata & IIII:2 & $r: 1$ & & $r: 1$ & . & . \\
\hline Carex lasiocarpa & III:2 & III:1 & $\mathbf{r}: 1$ & $\mathrm{r}: 1$ & . & . \\
\hline Carex rostrata & III:2 & $\mathrm{r}:+$ & . & $r: 1$ & $\mathrm{r}: 2$ & . \\
\hline Betula nana & & I:t & & $r: 1$ & . & . \\
\hline Carex pauciflora & III: 1 & IV:1 & III: 1 & I: 1 & . & . \\
\hline Drosera rotundifolia & r:t & V:1 & IV:1 & $r: 1$ & . & . \\
\hline Scirpus cespitosus & III:2 & IV:3 & IV:2 & $r:+$ & . & . \\
\hline Vaccinium oxycoccos & $\mathrm{V}: 2$ & V:1 & $\mathrm{V}: 2$ & $\mathrm{~V}: 2$ & I:1 & . \\
\hline Andromeda polifolia & IV:1 & $\mathrm{V}: 2$ & $V: 2$ & V:1 & $r: t$ & 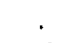 \\
\hline Eriophorum vaginatum & IV:2 & $\mathrm{V}: 2$ & IV $: 2$ & $\mathrm{~V}: 2$ & IV:2 & $\mathbf{r}: 1$ \\
\hline Dactylorhiza maculata & II:1 & I:+ & $r: 1$ & $\mathrm{I}:+$ & $r: 1$ & r:t \\
\hline Carex nigra & $\mathrm{r}: 1$ & II:1 & . & I:1 & I:t & $r: t$ \\
\hline Potentilla erecta & II:t & & . & & $\mathrm{r}: 1$ & . \\
\hline Vaccinium uliginosum & II:1 & II:1 & $\mathrm{V}: 2$ & $\mathrm{~V}: 2$ & $\mathrm{~V}: 2$ & . \\
\hline Calluna vulgaris & . & IV:2 & $V: 3$ & $\mathrm{~V}: 2$ & IV:1 & . \\
\hline Vaccinium vitis-idaea & $r: 1$ & r. & . & III:1 & $\mathrm{V}: 2$ & V:3 \\
\hline Vaccinium myrtillus & $r: 1$ & . & . & IV:2 & $V: 3$ & IV:3 \\
\hline Listera cordata & . & . & . & $\mathbf{r}:+$ & I:t & $V: 1$ \\
\hline Melampynum pratense & r:t & . & r:t+ & II:1 & $\mathrm{I}: 1$ & . \\
\hline Dryopteris carthusiana & . & . & . & $\mathrm{r}: 2$ & II: 1 & r:t+ \\
\hline Anthoxanthum odoratum & . & . & . & $r:+$ & $\mathrm{I}: 2$ & . \\
\hline Luzula multiflora & . & . & . & . & I:1 & - \\
\hline \multicolumn{7}{|l|}{ Tree seedlings } \\
\hline Pinus uncinata var. rotundata & $r:+$ & V:t+ & IV:+ & III:+ & II:+ & $\mathrm{r}: 1$ \\
\hline Picea abies & . & . & . & I:t & III:1 & III:2 \\
\hline Betula pubescens & $r: t$ & . & . & $r:+$ & III:1 & r:t \\
\hline Sorbus aucuparia & . & . & . & $r: 1$ & II:1 & . \\
\hline Abies alba & . & & . & $\mathrm{r}:+$ & I:t+ & $r:+$ \\
\hline
\end{tabular}

not fulfilled when a dense layer of Vaccinium remains. It is unlikely that such a cyclic process has occurred on a large scale in the small Jura bogs. Nevertheless, it might well be the case that small transient patches of pine forest have developed in the past. Such ancient woodland phases have been demonstrated elsewhere by stratigraphical analyses of peat bogs and the discovery of fossil trees (MUNAUT \& CASPARIE 1971, MCNALLY \& DOYLE 1984a, 1984b, PILCHER et al. 1995). In the Jura bogs there is little macrofossil evidence for such ancient pine forests. Nevertheless, layers with much higher pine-pollen content and associated macroremains, which indicate that there were several pine forest phases during the Atlantic and Subboreal periods, were identified by REILLE (1991) in one of the largest bogs of the Jura Mountains (Frasne, France).

Following REILle (1991) and FeLDMEYER-CHRISTE (1990), it is proposed that the phytocoenoses with tall and dense bog-pine trees (coenotaxa No. 3 and No. 4) have appeared 
Table 5. Synthetic tabular representation of the principal moss synusial elementary syntaxa of bog-pine-dominated vegetation in the uncut oligotrophic mires of the Jura Mountains (see complete explanation in Tab. 2). A short description of each syntaxon is given in Appendix. Rare species are not listed.

\begin{tabular}{|c|c|c|c|c|c|c|}
\hline $\begin{array}{l}\text { Moos layer syntaxon } \\
\text { Number of relevés } \\
\text { Total number of species }\end{array}$ & $\begin{array}{c}\text { M314 } \\
8 \\
7 \\
\end{array}$ & $\begin{array}{c}\text { M312 } \\
12 \\
17 \\
\end{array}$ & $\begin{array}{c}\text { M306 } \\
40 \\
29 \\
\end{array}$ & $\begin{array}{c}\text { M302 } \\
23 \\
20 \\
\end{array}$ & $\begin{array}{c}\text { M304 } \\
39 \\
28 \\
\end{array}$ & $\begin{array}{c}\text { M327 } \\
13 \\
24 \\
\end{array}$ \\
\hline Sphagnum subsecundum & II: 1 & . & $\mathrm{r}: 1$ & $r: 1$ & . & $\cdot$ \\
\hline Drepanocladus fluitans & II:1 & & $r: 1$ & . & . & • \\
\hline Sphagnum cuspidatum & V:5 & III: 2 & I:t & & 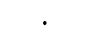 & \\
\hline Sphagnum angustifolium & II: 2 & I:1 & $\mathrm{V}: 2$ & III:2 & $\mathrm{V}: 2$ & II:2 \\
\hline Sphagnum tenellum & $r: 2$ & $\mathrm{~V}: 4$ & I:t & $\cdot$ & . & r \\
\hline Sphagnum papillosum & . & III:2 & r:t & $\mathbf{r}: 1$ & & \\
\hline Sphagnum magellanicum & . & IV:1 & $\mathrm{V}: 2$ & $\mathrm{~V}: 2$ & $\mathrm{~V}: 2$ & I:1 \\
\hline Mylia anomala & ${ }^{\circ}$ & II:+ & I:t & . & $\cdot$ & r. \\
\hline Cephalozia connivens & . & . & I:+ & & $r:+$ & e \\
\hline Sphagnum rubellum & . & $\mathrm{V}: 2$ & $\mathrm{~V}: 2$ & $\mathrm{r}: 2$ & $\mathrm{r}: 2$ & r \\
\hline Sphagnum fuscum & $\cdot$ & $r: 1$ & IV:2 2 & $V: 2$ & & 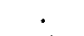 \\
\hline Aulacomnium palustre & $\cdot$ & $\mathrm{r}: 1$ & $\mathrm{~V}: 1$ & III: 1 & III:1 & $\mathrm{r}: 1$ \\
\hline Dicranum affine & . & r:t+ & III:1 & III:1 & II:1 & I:1 \\
\hline Sphagnum capillifolium & . & $r: 2$ & II: 1 & $\mathrm{~V}: 3$ & $\mathrm{~V}: 2$ & $\mathrm{r}: 2$ \\
\hline Polytrichum strictum & . & $\mathrm{r}: 1$ & $V: 1$ & $V: 2$ & $\mathrm{~V}: 1$ & $\mathrm{r}: 2$ \\
\hline Hylocomium splendens & . & . & & $r:+$ & II:+ & $\mathrm{V}: 2$ \\
\hline Pleurozium schreberi & . & . & II: 1 & II 1 & III:1 & $\mathrm{V}: 3$ \\
\hline Dicranum polysetum & . & . & . & r:t & II:1 & V:1 \\
\hline Sphagnum centrale & . & . & $\mathrm{r}: 1$ & . & I: 1 & \\
\hline Ptilium crista-castrensis & . & . & . & - & I: 1 & IV:1 \\
\hline Dicranum scoparium & . & . & . & . & I:1 & III:1 \\
\hline Rhytidiadelphus loreus & . & . & . & . & $\mathrm{r}: 1$ & II:1 \\
\hline Rhytidiadelphus triquetrus & $\cdot$ & . & . & r:t & r:t & II:2 \\
\hline Sphagnum girgensohnii & $\cdot$ & $\cdot$ & $r: 2$ & . & II $: 1$ & . \\
\hline Sphagnum russowii & & 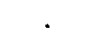 & $\mathrm{r}: 1$ & . & I:2 & . \\
\hline
\end{tabular}

recently on the Jura bogs as a result of continuous human impact since the 18th century (peat cutting, drainage). It is, however, probable that the bog-pine has always existed in this ecosystem since the onset of the post-glacial period. Its distribution earlier was probably different from that of today, most populations having developed on the fens or in association with the spruce forest at the bog margins, but possibly also in isolated stands or individually on the oligotrophic bog (Freléchoux 1997). Contrary to REILLE (1991) and FELDMEYER-CHRISTE (1990), we do not believe that bog-pines were ever planted in the Jura bogs, at least not on a large scale. Based on historical documents, BÉGEOT \& RICHARD (1996) have proved that bog-pines were never planted in the large mire of Frasne (France), unlike some other tree species. Recently MrTCHELL et al. (in press) stressed that forest clearance in the vicinity of the bogs in the Jura Mountains could have changed their local climate, increasing the influence of winds and the drying up of the peat surface, thus permitting bog-pine encroachment. The survival potential of Pinus uncinata var. rotundata is very high and has allowed this species to thrive in many ecological situations, such as wet and oligotrophic environments. The small contribution of Pinus in the former stratigraphical layers, as compared to surface layers, can be explained by the stress exerted on the plants by a high water table, which allowed only limited pollen production (GIERTYCH 1967, EllENBERG 1978). In conclusion, the different bog-pine-dominated vegetation types described in this study have 


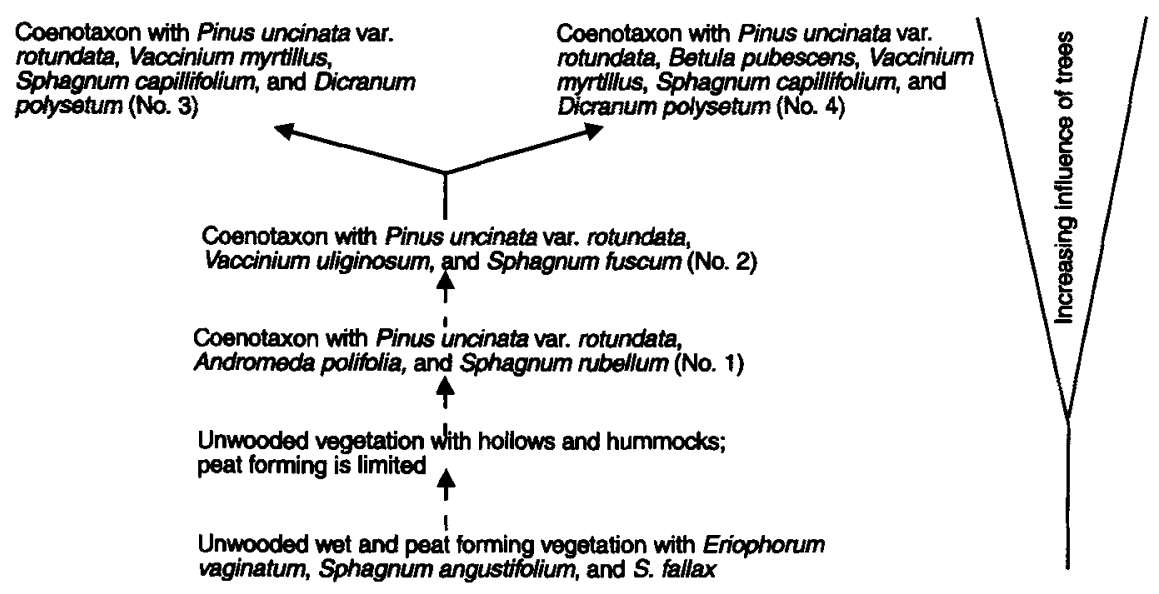

Fig. 5. Primary succession of the phytocoenoses towards a bog-pine-dominated vegetation in oligotrophic mires affected by drainage.

most probably all existed concurrently since the beginning of the development of the Jura bogs, which would point to local polyclimax communities induced by differences in the water table. What has changed during the evolution of the bogs is the balance between the different bog-pine communities. In particular, the postclimax described by NEUHÄUSL (1992), which corresponds to our coenotaxa No. 3 and No. 4, has spread since the Jura bogs began to be affected by recent drainage. As a result, the synusial communities characteristic of hollows and wet lawns are threatened in many of the Jura bogs.

Acknowledgements: The authors thank S. Dingwall and R.K. Biddle for translation supervisions, and are also indebted to the anonymous reviewers for constructive comments on the manuscript. This research forms part of the PhD. thesis of one of us (F.F.) and was funded by the Swiss National Research Fund (Grant No. 31-34047.92).

\section{REFERENCES}

ANDRUS R.E., WAGNER D.J. \& TITUS J.E. (1983): Vertical zonation of Sphagnum mosses along hummock-hollow gradients. Canad. J. Bot. 61: 3128-3139.

BARKMAN J.J. (1973): Synusial approaches to classification. In: WHITTAKER R.H. (ed.), Classification of plant communities, Junk, The Hague, pp. 435-491.

BÉGEOT C. \& RICHARD H. (1996): L'origine récente des peuplements de Pin à crochets (Pinus uncinata MÜLLER ex MIRBEL) sur la tourbière de Frasne et exploitation de la tourbe dans le Jura. Acta Bot. Gallica 143: 47-53.

ButTler A., CORNALI P. \& RiChARD J.-L. (1983): La tourbière des Pontins sur St-Imier. Matér. Levé Géobot. Suisse 59: 1-79.

BRAUn-BlanqueT J. (1964): Pflanzensoziologie. Grundzüge der Vegetationskunde. Ed. 3. Springer Verlag, Wien.

CHASTAIN A. (1952): Recherches écologiques et floristiques sur le "Pinetum" de la Haute-tourbière de la Vraconnaz (Jura helvétique vaudois). Recueil Trav. Inst. Bot. Univ. Montpellier, Supplément 2: 1-176.

CORLeY M.F.V., CRUNDWEll A.C., DULl R., HILl M.O. \& SMITH A.J.E. (1981): Mosses of Europe and the Azores: an annotated list of species, with synonyms from the recent literature. J. Bryol. 11: 609-689.

DANG Q.L. \& LIEFFERS V.J. (1989): Assessment of patterns of response of tree ring growth of black spruce following peatland drainage. Canad. J. Forest Res. 19: 924-929.

DIERSSEN K. (1977): Klasse Oxycocco-Sphagnetea. In: OBERDORFER E. (ed), Süddeutsche Pflanzengesellschaften 1, Ed. 2. Gustav Fischer Verlag, Stuttgart., pp. 273-292. 
DIERSSEN K. (1980): Some aspects of the classification of oligotrophic and mesotrophic mire communities in Europe. Colloq. Phytosoc. 7: 399-423.

ELLENBERG H. (1978): Vegetation Mitteleuropas mit den Alpen in ökologischer Sicht. Ed. 2. Eugen Ulmer, Stuttgart.

ELlenberg H., Weber H.E., DÜll R., WIRTH V., WeRneR W. \& PAUlissen D. (1991): Zeigerwerte von Pflanzen in Mitteleuropa. Scripta Geobot. 18: 1-258.

FELDMEYER-CHRISTE E. (1990): Etude phytoécologique des tourbières des Franches-Montagnes (cantons du Jura et de Berne, Suisse). Matér. Levé Géobot. Suisse, 66: 1-163.

FRELÉCHOUX F. (1997): Etude du boisement des tourbières hautes de la châ̂ne jurassienne: typologie et dynamique de la végétation - approche dendroécologique des peuplements arborescents. $\mathrm{PhD}$. Thesis, Université de Neuchâtel, Neuchâtel.

FRELECHOUX F., BUTTLER A., SCHWEINGRUBER F.H. \& GOBAT J.-M. (2000): Stand structure, invasion, and growth dynamics of bog-pine (Pinus uncinata var. rotundata) in relation to peat cutting and drainage in the Jura Mountains, Switzerland. Canad. J. Forest Res. 30: 1114-1126.

GIERTYCH M. (1967): Generative reproduction. In: BIAŁOBOK S. \& ZELAWSKI W. (eds.), Outline of physiology of Scots pine, PWN, Poznań, pp. 303-330.

GILET F., DE FOUCAULT B. \& JULVE P. (1991): La phytosociologie synusiale intégrée: objets et concepts. Candollea 46: 315-340.

GILLET F. \& GALLANDAT J.D. (1996): Integrated synusial phytosociology: some notes on a new multiscalar approach to vegetation analysis. J. Veg. Sci. 7: 13-18.

GROLLE R. (1983): Hepatics of Europe including the Azores: an annotated list of species, with synonyms from the recent literature. J. Bryol. 12: 403-459.

GRÜNIG P.E. (1955): Über den Einfluss der Entwässerung auf die Flachmoorvegetation und auf den Zuwachs der Fichte und Bergföhre im Flyschgebiet der Voralpen. Mitt. Schweiz. Anst. Forstl. Versuchswesen 31: $419-476$.

GRÜNIG A., VETTERLI L. \& WILDI O. (1984): Inventaire des hauts-marais et marais de transition de Suisse. Swiss Federal Institute for Forest, Snow and Landscape, Birmensdorf.

GRÜNIG A., VETTERLI L. \& WILDI O. (1986): Les hauts-marais et marais de transition de Suisse. Report of the Swiss Federal Institute for Forest, Snow and Landscape, Birmensdorf.

GuINOCHeT M. (1955): Carte des groupements végétaux de la France. Pontarlier 5-6, 1/20.000. CNRS, Paris. GUINOCHET M. (1973): Phytosociologie. Masson, Paris.

KRISAÏ R. (1960): Pflanzengesellschaften aus dem Ibmer Moor. Jahrb. Oberösterr. Musealvereins 105: 155-208.

LANDOLT E. (1977): Ökologische Zeigerwerte zur Schweizer Flora. Veröff. Geobot. Inst. ETH, Stiftung Rübel Zürich 64: 1-208.

LIEFFERS V.J. \& ROTHWELL R.L. (1986): Effects of depth of water table and substrate temperature on root and top growth of Picea mariana and Larix laricina seedlings. Canad. J. Forest Res. 16: 1201-1206.

LIEFFERS V.J. \& ROTHWELL R.L. (1987): Rooting of peatland black spruce and tamarack in relation to depth of water table. Canad. J. Bot. 65: 817-821.

MCNALLY A. \& DOYLE G.J. (1984a): A study of sub-fossil pine layers in a raised bog complexe in the Irish midlands: 1. Palaeowoodland extent and dynamics. Proc. Roy. Irish Acad. Sect. B 84 (6-7): 57-70.

MCNALLY A. \& DOYLE G.J. (1984b): A study of sub-fossil pine layers in a raised bog complexe in the Irish midlands: 2. Seral relationships and floristics. Proc. Roy. Irish Acad. Sect. B 84 (6-7): 71-81.

MATTHEY W. (1964): Observations écologiques dans la tourbière du Cachot. Bull. Soc. Neuchâteloise Sci. Nat. 87: $103-133$.

MATTHEY W. (1971): Ecologie des insectes aquatiques d'une tourbière du Haut-Jura. Rev. Suisse Zool. 78: $367-536$.

MITCHELL E.A.D., VAN DER KNAAP W.O., VAN LEEUWEN J.F.N., BUTTLER A., WARNER B.G. \& GOBAT J.-M. (in press): The palaeoecological history of Praz-Rodet bog (Swiss Jura) based on pollen, plant macrofossils and testate Amoeba (Protozoa). The Holocene.

MOORE J.J. (1968): A classification of the bogs and wet heaths of northern Europe. Pflanzensoziologische Systematik, Den Haag, pp. 306-320.

MUNAUT A.V. \& CASPARIE W.A. (1971): Etude dendrochronologique des Pinus silvestris subfossiles provenant de la tourbière d'Emmen (Drenthe, Pays-Bas). Rev. Palaeobot. Palynol. 11: 201-226.

MÜLLER-DOMBOIS D. (1964): Effects of depth of water table on heigh growth of tree seedlings in a greenhouse. Forest Sci. 10: 306-316. 
NEUHÄUSL R. (1969): Systematisch-soziologische Stellung der baumreichen Hochmoorgesellschaften Europas. Vegetatio 18: 104-121.

NEUHÄUSL R. (1972): Subkontinentale Hochmoore und ihre Vegetation. Stud. Českoslov. Akad. Věd 13: 1-121.

NEUHÄUSL R. (1992): Primary and secondary succession on wooded peat-bogs. Acta Soc. Bot. Poloniae 61: 89-102.

OBERDORFER E. (1957): Süddeutsche Pflanzengesellschaften. Pflanzensoziologie 10: 1-564.

OBERDORFER E. (ed.) (1977): Süddeutsche Pflanzengesellschaften 1.Ed. 2. G. Fischer Verlag, Stuttgart.

OBERDORFER E. (ed.) (1992) Süddeutsche Pflanzengesellschaften 4. Ed. 2. G. Fischer Verlag, Stuttgart.

OHLSON M. \& ZACKRISSON O. (1992): Tree establishment and microhabitat relationships in north Swedish peatland. Canad. J. Forest Res. 22: 1869-1877.

PAYANDEH B. (1973): Analyses of a forest drainage experiment in northern Ontario. I. Growth analysis. Canad. J. Forest Res. 3: 387-398.

Pilcher J.R., BAILlIE M.G.L., BROWN D.M., MCCORMAC F.G., MACSWEenEy P.B. \& MCLAWRENCE A.S. (1995): Dendrochronology of subfossil pine in the north of Ireland. J. Ecol. 83: 665-671.

RichARD J.-L. (1961): Les forêts acidophiles du Jura. Matér. Léve Géobot. Suisse 38: 1-164.

REILLE M. (1991): L'origine de la station de pin à crochets de la tourbière de Pinet (Aude) et de quelques stations isolées de cet arbre dans les Vosges et le Jura. Bull. Soc. Bot. France 138, Lettres Bot. 2: 123-148.

ROYER J.-M., VADAM J.-C., GILLET F., AUMONIER J.-P. \& AUMONIER M.-F. (1978): Etude phytosociologique des tourbière acides du Haut-Doubs. Réflexions sur leur régénération et leur génèse. Doc. Phytosoc. 7: 295-344.

SANDOZ H. (1982): Le complexe des Pins dits "de montagne". Analyse historique des principaux binômes utilisés: Pinus montana Müller, Pinus mugo TURRA, Pinus mughus SCOPOLI, Pinus pumilio HaENKE et Pinus uncinata RAMOND. Rev. Gén. Bot. 89: 121-129.

SANDOZ H. (1987): Recherches taxonomiques, biogéographiques et phytoécologiques sur les principaux conifères subalpins des Alpes: mélèze d'Europe, pin cembro, pin à crochets et pin mugho. $\mathrm{PhD}$. Thesis, Université d'Aix-Marseille III, Marseille.

SCHMID J., BOGENRIEDER A. \& SCHWEINGRUBER F.H. (1995): Verjüngung und Wachstum von Moor-Kiefer (Pinus rotundata LiNK) und Fichten (Picea abies (L.) H. KARSTEN) in Mooren des Südöstlichen Schwarzwaldes (Süddeutschland), Mitt. Eidgenöss. Forsch. Anst. Wald Schnee Landschaft 70: 175-223.

SCHNEEBELI M. (1991): Hydrologie und Dynamik der Hochmoorentwicklung. PhD. Thesis, ETH, Zürich.

SCHULTHESS J. (1990): Der Einfluss von Entwässerung auf Bewaldung eines Hochmoores: Eine Studie zur rezenten Bewaldungsentwicklung am Etang de la Gruère (JU). MSc. Thesis, Geogr. Inst. Univ. Zürich-Irchel, Zürich.

SCHWEINGRUBER F.H. (1996): Tree rings and environment, dendroecology. Swiss Federal Institute for Forest, Snow and Landscape Research, Berne, Stuttgart, Vienna, Haupt.

SEPPALA K. (1969): Postdrainage growth of Norway spruce and Scots pine on peat. Acta Forest. Fenn. 93 : $1-89$.

STANEK W. (1977): Ontario clay belt peatlands - are they suitable for forest drainage? Canad. J. Forest Res. 7: $656-665$

STRAVINSKENE V.P. (1983): Dynamics of early and late wood in the annual rings of trees and its change due to the forest drainage. Soviet J. Ecol. 14: 324-328.

TUTIN T.G., HeYWOOD V.H., BuRges N.A., Valentine D.H., Walters S.M. \& WebB D.A. (eds.) (1964-1980): Flora europaea I-5. Cambridge University Press, Cambridge.

WESTHOFF V. \& VAN DER MAAREL E. (1978): The Braun-Blanquet approach. In: WHITTAKER R.H. (ed.), Classification of plant communities, Junk, The Hague, pp. 287-399.

WILDI O. (1989): A new numerical solution to traditional phytosociological tabular classification. Vegetatio 81: 95-106.

WILDI O. \& ORLOCI L. (1996): Numerical exploration of community patterns. A guide to the use of MULVA-5. SPB Academic Publishing, The Hague.

ZoBEL M. (1988): Autogenic succession in boreal mires - a review. Folia Geobot. Phytotax. 23: 417-445.

Received 17 May 1999, received and accepted 17 May 2000

Encl. Appendix pp. 287-288 


\section{APPENDIX}

List of the 30 synusial elementary syntaxa of bog-pine-dominated vegetation presented in Tab. 1, with a short description. Not listed are 13 elementary syntaxa that were accidental. Syntaxa numbers are those kept from the whole typology (FrELECHOUX 1997). The letters T (trees), S (shrubs), H (herbs) and M (mosses) come before the number according to their respective layer. Those syntaxa which explain most of the vegetation spatial structure and which were used for the generalized dynamic model (see Fig. 3 and Tab. 2 to 5) are marked with an asterisk $\left({ }^{*}\right)$.

T5*. Monospecific tree layer syntaxon with Pinus uncinata var, rotundata. Both Picea abies and Betula pubescens are missing. Synusiae occur in closed, medium or tall pine forests.

T6. Tree layer syntaxon with Pinus uncinata var. rotundata, Betula pubescens, and Sorbus aucuparia. Synusiae occur in closed, tall pine forests.

T8*. Tree layer syntaxon with Pinus uncinata var. rotundata, Betula pubescens, and Picea abies. Synusiae occur in closed, tall pine forests.

S101*. Monospecific shrub layer syntaxon with Pinus uncinata var. rotundata. Synusiae occur in open to closed pine forests.

S102*. Shrub layer syntaxon with dominance of Pinus uncinata var. rotundata. Both Picea abies and/or Betula pubescens are present. Synusiae occur in open to closed pine forests.

S103*. Shrub layer syntaxon with Betula pubescens and Pinus uncinata var. rotundata. The pubescent birch is more dominant. Synusiae occur in the understorey of half-closed to closed tall pine forests.

S108. Shrub layer syntaxon with Picea abies, Betula pubescens, and Sorbus aucuparia. Synusiae occur mainly in spruce forests.

H201*. Herb layer syntaxon with Drosera rotundifolia, Carex pauciflora, Andromeda polifolia, Eriophorum vaginatum, Vaccinium oxycoccos, Pinus uncinata var. rotundata, Scirpus cespitosus, and Calluna vulgaris. Synusiae occur on wet lawns at the edges of the hollows.

H202*. Herb layer syntaxon close to H201. Most of the hygrophilous plants are missing. Here Vaccinium uliginosum is more frequent and has greater cover. Synusiae occur on less wet lawns.

H203*. Herb layer syntaxon with Vaccinium uliginosum, Calluna vulgaris, Eriophorum vaginatum, Vaccinium oxycoccos, Andromeda polifolia, and Vaccinium myrtillus. Synusiae occur on drier lawns and hummocks.

$\mathrm{H} 205^{*}$. Herb layer syntaxon with Vaccinum myrtillus, V. vitis-idaea, and V. uliginosum. Synusiae occur on drier and more shaded hummocks in pine, birch, and spruce forests.

H206*. Herb layer syntaxon with Vaccinium vitis-idaea, Listera cordata, and Vaccinium myrtillus. Synusiae occur in very shaded locations mainly in spruce forests. It also occurs in the tall pine forests, in the understorey of the tall and dense V. myrtillus-layer.

H208*. Herb layer syntaxon with Carex limosa, Scheuchzeria palustris, Vaccinium oxyccocos, Andromeda polifolia, and Eriophorum vaginatum. Synusiae occur in well-lit and moist situations, in hollows and in the wettest borders in the middle of raised bogs.

M302*. Moss layer syntaxon with Sphagnum capillifolium, S. fuscum, S. magellanicum, and Polytrichum strictum. Synusiae occur in half-light locations on dry lawns and hummocks in pine- and birch-wooded bogs.

M304*. Moss layer syntaxon with Sphagnum capillifolium, S. magellanicum, S. angustifolium, and Polytrichum strictum. Synusiae occur in shady and dry locations in pine, birch and spruce forests, mainly under a Vaccinium-layer.

M305. Moss layer syntaxon with Sphagnum angustifolium, S. magellanicum, Polytrichum strictum, and Aulacomnium palustre. The dominant moss is Sphagnum angustifolium. Synusiae occur mainly in ditches after peat cutting and form very wet lawns.

M306*. Moss layer syntaxon with Sphagnum rubellum, S. magellanicum, Polytrichum strictum, Aulacomnium palustre, Sphagnum angustifolium, and $S$. fuscum. Synusiae occur in open and wet locations, on wet lawns at the borders of the oligotrophic hollows in the middle of the raised bogs.

M307. Moss layer close to M306, with Sphagnum rubellum, S. magellanicum, S. angustifolium, and S. fuscum. A number of mosses, including Polytrichum strictum, Aulacomnium palustre, and Dicranum affine are missing. Synusiae occur on the wettest and most oligotrophic lawns at the borders of the oligotrophic hollows. 
M310. Moss layer syntaxon with Sphagnum rubellum and the hepatics Kurzia pauciflora, Mylia anomala, Cephalozia connivens, and Calypogeia sphagnicola. Synusiae occur on well-lit and moist lawns or on wet, bare or trampled peat. Hepatics might point to increasing peat mineralization.

M311. Moss layer syntaxon poor in species with Sphagnum cuspidatum and S. magellanicum. Synusiae sometimes relictual on well-drained raised bogs, sometimes pioneer on wet peat after peat cutting.

M312*. Moss layer syntaxon with $S$. rubellum, Sphagnum tenellum, $S$. magellanicum, $S$. papillosum, and $S$. cuspidatum. Synusiae occur on the wettest borders of the oligotrophic hollows.

M314*. Moss layer syntaxon poor in species with Sphagnum cuspidatum and Drepanocladus fluitans. Synusiae occur only in the most oligotrophic hollows.

M326. Moss layer syntaxon poor in species, with only Pleurozium schreberi and Hylocomium splendens. Synusiae occur in very dry and half-shaded locations, chiefly in birch forests, but also in pine forests.

M327*. Moss layer syntaxon with Pleurozium schreberi, Hylocomium splendens, Dicranum polysetum, and Ptilium crista-castrensis. Synusiae occur under the dry and shadiest locations, only in tall pine forests.

M329. Moss layer syntaxon with Dicranum affine, Polytrichum strictum, and Pleurozium schreberi, but with Hylocomium splendens missing. Synusiae occur in light and dry locations in open pine- and birch-wooded bogs.

M330. Moss layer with Aulacomnium palustre, Sphagnum angustifolium, and Pleurozium schreberi. Synusiae occur in meso-oligotrophic locations in wooded fens but also in pine-dominated raised bogs. In these bogs, the presence of Aulacomnium palustre may point to increasing peat mineralization.

M333. Moss layer syntaxon with Dicranodontium denudatum and Tetraphis pellucida. Synusiae occur in dry situations on rotted wood or on bare peat.

M334. Moss layer syntaxon with Dicranodontium denudatum, Sphagnum capillifolium, S. magellanicum, and Mylia anomala. Synusiae occur in wet, shady locations on bare peat.

M336. Hepatic-dominated moss layer syntaxon with Cephalozia connivens, Mylia anomala, Kurzia pauciflora, Calypogeia sphagnicola, Calypogeia neesiana, and Dicranodontium denudatum. Synusiae occur on bare or trampled peat.

M343. Lichen syntaxon with Cladonia rangiferina (L.) WEBER ex WIGG and Cladonia arbuscula (WALLR.) FLOTOW. Synusiae occur in dry, light to shady locations in several pine-dominated coenotaxa. 